\title{
The Development of the Hydroid Corymorpha nutans M. Sars from the Egg.
}

\author{
By \\ W. J. Rees, \\ Rescarch Assistant at the Plymouth Laboratory.
}

With 2 Figures in the Text.

DURING the summer of 1936 I obtained mature specimens of the medusa* of Corymorpha nutans at Plymouth. An account of the early development of the hydroid reared from the fertilized eggs of these is given below. Young polyps of this species have been figured by Allman (1871) and by Hartlaub (1907). Allman found his young polyps developing apparently from the rooting filaments of the parent hydroid which had become free. Hartlaub figures and assigns young polyps which he found in the plankton at Helgoland to this species.

A large number of medusae were captured off the Eddystone on May 18th, 1936. These were isolated overnight in a finger-bowl of sea-water. Next morning several of the medusae which were ripe had shed their sexual products. Such medusae were disintegrating, although others in the same bowl but not quite ripe were quite healthy and swimming actively. Both healthy and disintegrating medusae were removed by pipette. Left on the bottom of the bowl were a number of large opaque eggs easily visible to the naked eye. When observed they had evidently been fertilized and had a distinct yellowish pellicle around them. None had hatched on May 21st, but by May 25th a number of young had emerged and others were emerging (Fig. 1, A-D).

These liberated eggs measure from $0 \cdot 26-0 \cdot 28 \mathrm{~mm}$. in diameter. Eggs obtained from mature medusae on May 26th exhibited activity and movement and these are figured (Fig. 2, A-F). The pellicle of the egg is very elastic and is pushed out into broad pseudopodial-like growths on the under side into contact with the substratum to which the pellicle adheres. The so-called "pseudopodia" then withdraw into the main body and the dilated pellicle shrivels up into a small tube. Several of these may be formed (Fig. 2, F) and they anchor the egg to the substratum. They may be termed anchoring filaments.

* Steenstrupia (Corymorpha) nutans of the Plymouth Marine Fauna. For a description of this medusa see Browne (1896). 
The young developed directly out of the eggs into young polyps instead of emerging as ciliated planulae which is the more usual way of development among hydroids. In this respect it resembles Corymorpha palma Torrey, 1902 (see Torrey, 1907). According to Torrey, however, the larva of C. palma emerges from the egg-case and wanders aimlessly about before settling down. My specimens were very inactive and the young hydroids grew out of the egg-cases and proceeded to differentiate into hydrocaulus and hydranth, the latter developing tentacles. The

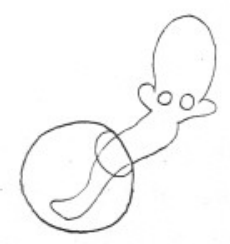

B

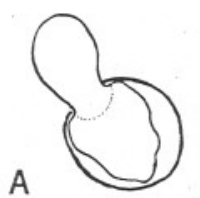

Fra. 1.-A-D, various stages of development of young polyps of Corymorpha nutans; Plymouth, 25.v.36.

proximal ends of the hydrocauli were still inside the egg-cases in the majority of the specimens and would probably have remained so if the bowl had been undisturbed. The proximal ends of the young polyps, however, were not attached in any way to the egg-case.

Young polyps taken on May 26th possessed 4-6 oral tentacles and 6-8 aboral tentacles. The measurements of a typical young hydroid at this age are given below :-

Maximum length of hydrocaulus . . . . $1.6 \mathrm{~mm}$.

Maximum diameter of hydrocaulus . . . $0 \cdot 14 \mathrm{~mm}$.

Diameter of hydranth . . . . . . $0.3 \mathrm{~mm}$.

Length of oral tentacles . . . . . . $0.12 \mathrm{~mm}$.

Length of aboral tentacles . . . . . . $0.5 \mathrm{~mm}$. 
After another week one of the polyps had developed 8 oral tentacles and 15 aboral tentacles. By this time, June 3rd, the young polyps had developed rooting filaments (the "frustules" of Allman) on the proximal part of the hydrocaulus. They were always few in number and each consisted of a fine filament with a clavate tip by means of which the polyps attached themselves to the substratum. After secreting a thin perisarc around itself the protoplasmic connexion with the hydrocaulus breaks down and eventually disappears, leaving the perisarc as an empty anchoring filament. The formation of this filament and its subsequent


D

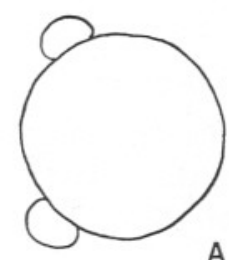

A

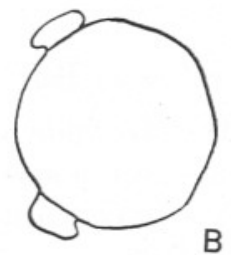

B

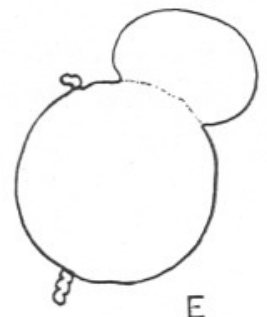

E
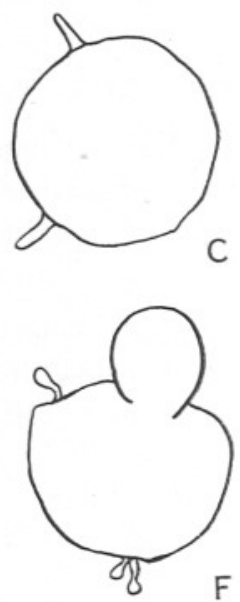

Fig. 2.-A-F, movements shown by a single fertilized egg of Corymorpha nutans during thirty minutes; Plymouth, 26.v.36.

development appears to be identical with the process described by Torrey (1907) for C. palma.

On June 23rd the single polyp left in the bowl developed the rudiment of a gonophore stalk on the body of the hydranth on the distal side of the aboral tentacles. During the next few days the rudiment became divided but did not develop further. At this age the polyp possessed 15 oral and 17 aboral tentacles and a distinct, firm, brownish pellicle. The pellicle, however, was present on one of two polyps on June 3rd as a very thin, delicate membrane. The development was not studied further. 


\section{REFERENCES.}

Allman, G. J. 1871-72. A Monograph of the Gymnoblastic or Tubularian Hydroids. Ray Society, London, pp. 1-450.

Browne, E. T. 1896. On British Hydroids and Medusae. Proc. Zool. Soc., London, pp. 459-500.

Hartlaub, C. 1907. Craspedote Medusen, 1 Teil, 1 Lief., Codoniden und Cladonemiden. Nordisches Plankton, Lief. 6, XII.

Marine Biological Association. 1931. Plymouth Marine Fauna, Second Edition.

SARS, M. 1835. Beskrivelser og Jagt., etc. (Bergen).

Torrey, H. B. 1902. The Hydroida of the Pacific Coast of N. America, with especial reference to the species in the Collection of the University of California. Univ. Calif. Publ. Zool., Vol. I, pp. 1-104, Pls. 1-11, November, 1902.

1907. Biological Studies on Corymorpha. II. The Development of C. palma from the Egg. Ibid., Vol. III, No. 12, pp. 253-298, 33 text figs., May, 1907. 